\title{
THE LAW OF PICKETING IN ALBERTA
}

\begin{abstract}
INNIS CHRISTIE*
The author discusses the law of picketing with special emphasis on cases decided in Alberta and on the peculiarities of the Alberta labour legislation. The law relating to picketing is considered in two categories: Picketing in support of unlawful strikes and picketing in support of lawful strikes. In this context the author discusses when picketing can be enjoined or give rise to damage actions. The author recommends a rational assessment of when, where and how picketing should be allowed in the context of the Canadian system of collective bargaining, with less reliance in the control of picketing on the torts of inducing breach of contract, conspiracy and intimidation.
\end{abstract}

It may be that the era when a lawyer can assume that picketing means picketing in connection with a labour dispute is fast coming to a close. Recently I heard the Executive Director of the National Welfare Rights Organization in the United States describe the tactics of a consumer boycott, aimed at forcing a nationwide chain of stores to extend its credit facilities to welfare recipients. Thus far lawyers have paid little attention to the interests that the law will have to balance in determining the limits of the rights of such groups. When they do, I hope that these new problems will be faced in terms of how best to balance competing demands in a complex society rather than in terms of outmoded legal conceptualizing which never took into account more than some of the interests involved.

Labour law will have to serve as the developed example of the way that the law deals with economic pressure through picketing, and I for one am not at all happy that it is a very good example. But the law of picketing in labour relations can hardly be treated as nothing more than a starting point for law to deal with new power confrontations in society. The ultimate economic conflict which underlies labour management relations is itself of more importance than ever in Canada. It is only three years ago that the labour movement mounted its concerted attack on the use of the ex parte injunction. The Rand Commission, appointed in Ontario to study the law of picketing and injunctions, reported just last fall ${ }^{1}$ and now the Privy Council's Task Force on Labour Relations has reported, ${ }^{2}$ after a comprehensive inquiry into the whole field. I don't intend to comment at any. length on either of these reports. I mention them only as very current evidence of the importance of the long-standing labour-management confrontation in strikes and on the picket line. In the words of the Task Force,

It is basic . . that we view the role of collective bargaining within the industrial

relations system as the most acceptable form for resolving conflict between enterprise and labour in our political economy. . . . The strike and lockout are part of that system and we accept them as such.

In considering the law of picketing my first and major concern will be to spell out as clearly as possible when picketing is illegal, for practical purposes, and when an injunction can be obtained. I will try to resist, but not too successfully, the urge to give my own views and

- B.A. (1958), LL.B. (1962), Diploma in Comparative Legal Studies (1964), LL.M. (1964), Professor, Faculty of Law, Queen's University.

Royal Commission Inquiry into Labour Disputes, August, 1968.

2 Canadian Industrial Relations: The Report of the Task Force on Labour Relations, December, 1968.

3 Id., at 167. 
those of the Task Force on changes that should be made. Then I will recapitulate the grounds of illegality, stressing the remedies that are available in each case. The injunction is the most important remedy so I will set out briefly labour's objections to its use and consider the response to those objections by the Alberta Legislature in section 94 (a) of the Alberta Labour Act."

At the outset the question must be raised whether our law of picketing takes due account of the right to free speech, which we might suppose that we have in some nebulous form. Free speech is, of course, an important constitutional issue in the law of picketing in the United States, it is part of the rhetoric of labour in the dispute over the use of the injunction, and if, as I have suggested, we are moving into an era where a whole new range of social demands will be put forward through the use of the picket line, the value of freedom of speech must surely be important in the balance struck by any newly developed law. ${ }^{5}$

In determining whether or not picketing is enjoinable, the first question is whether or not the picketing is in support of a legal strike. I will consider first picketing carried on other than in connection with an illegal strike and then turn to picketing in connection with a legal strike. Let it be understood, however, that all of the grounds upon which picketing in support of a legal strike may be enjoined may also be available where the strike is illegal. The illegality of the strike is one extra hurdle.

Section 95 of the Alberta Act provides,

95 (1) A strike or lockout is illegal,

(a) where the strike or lockout is in contravention of section 94, or

(b) where a collective agreement is in force.

Section 94 provides that where a notice to bargain has been given under section 72, no employee shall go on strike until the whole conciliation procedure, including a vote by the employees on whether to accept the

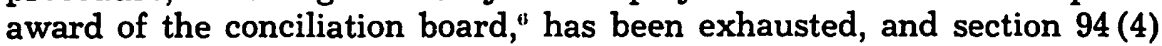
also requires that a majority of the employees must vote in favour of the strike in a vote supervised by the Board of Industrial Relations ${ }^{2}$ before any employee may go on strike. Sections 95 and 94 together, then, constitute the statutory definition of an illegal strike.

With regard to picketing, section 95 (2) goes on to provide:

(2) where a strike is illegal no trade union or member of the trade union or other person shall dissuade or endeavour to dissuade anyone from

(a) entering an employer's place of business, operations or employment,

(b) dealing in or handling the products of any person, or

(c) doing business with any person.

To get a sense of the way in which these provisions apply I will examine the legality of picketing at three stages of the labour-management relations: first, before the union is certified, that is when it is attempting to organize or gain recognition; second, during negotiations but before the full conciliation process has been exhausted and, third, while a collective agreement is in force.

4 R.S.A. 1955 , c. 167 as amended by S.A. 1957 , c. $38 ; 1958$, c. $82 ; 1959$, c. $35 ; 1960$, c. 54 ;

5 In Koss v. Kohn (1961) 30 D.L.R. (2d) 242 (B.C.C.A.) the Court rejected the contention that the B.C. Trade-Union Act, R.S.B.C. 1960, c. 384 . s. 3, was ultra vires in prohibiting picketing not in support of a legal strike on the ground either that it was prohibiting picketing not in support of a legal strike on the ground either that it was beyond the power of a provincial legislature to abrogate "freedom of speech" or
under the Canadian Bill of Rights, which was held to have no application to a under the Canadian

o Alberta Labour Act, R.S.A. 1955, c. 167, (as amended) s. 93(8).

7 Id., s. 94(4). 
In the early part of this century the bitterest labour disputes were fought over the issue of union recognition. In Alberta, as in every other major jurisidiction in North America, labour relations legislation now requires the employer to recognize a union supported by the majority of his employees and, in return, limits the use of economic force to gain recognition or to organize the employees. In most jurisdictions an uncertified union cannot picket an employer to force him to sign a collective agreement nor can a union picket to force employees to become members. In Ontario, for example, a strike is forbidden until the conciliation procedure under the Act has been exhausted, and only a certified union can invoke the procedure. ${ }^{8}$ In 1961, in Gagnon v. Foundation Maritime ${ }^{0}$ the Supreme Court of Canada established that, even where the provincial legislation makes no mention of picketing, picketing in support of an illegal strike is enjoinable.

Even before the Supreme Court ruled on the matter it was quite apparent that Canadian courts would not allow uncertified unions to exert economic pressure on employers. The 1957 Alberta case of Bennett and White v. Van Reeder ${ }^{10}$ is a good example of the judicial reaction to such activities. In that case the Operating Engineers attempted to get an agreement with Budd Brothers Ltd., who had a sub-contract from Bennett and White to excavate a tunnel in downtown Calgary. Members of the carpenters' union who were working for the head contractor refused to cross the picket line, in accordance with the requirements of their union's constitution. The picketing was enjoined and the injunction was upheld by the Appellate Division of the Alberta Supreme Court, on the ground that the pickets had induced the carpenters to breach their contracts of employment. The reasoning in the case is open to criticism, as is the very notion that the tort of inducing breach of contract has any place in the law of industrial conflict, and I shall return to these matters when I deal with picketing in support of a legal strike. For the moment the point that I wish to make is simply that, in the context of a system of labour relations that provides for certification of trade unions, the courts have, in Alberta and the other provinces of Canada, never lacked common law grounds upon which to enjoin picketing by an uncertified union.

In Alberta special express provision is made for organizational and recognition picketing. Section $64(3)$ provides,

(3) A trade union shall not be certified as a bargaining agent if, in the opinion of the Board, application for membership or membership in the trade union directly resulted from picketing of the place of business of the employer at which the employees affected are employed, or elsewhere.

Thus, the union gains nothing by organizational picketing and loses its chance to be certified by the Board of Industrial Relations and thus force the employer to bargain. ${ }^{11}$ The section gives rise to the basic dilemma: Should the employees be denied the opportunity to be represented by the union of their choice because the union has transgressed?

8 The Ontario Labour Relations Act, R.S.O. 1960, c. 202, ss. 54(2), 11 and 13.

o [1961) S.C.R. 435

10 (1956) 6 D.L.R. (2d) 326 (Alta. A.D.). See also Smith Bros. Construction Co. v. Jones [1955] 4 D.L.R. 255 (Ont. H.C.).

11 In one case the Alberta Board of Industrial Relations refused to certify the union, not because the employees who were union supporters had joined as a result of the picketing, but rather because they had been hired by the employer to satisfy the demands of pickets. Section 64 (3) was thus extended to cover a construction industry Asbestos Workers, Local 126 and Mastro Insulators Ltd. (1964) 64(3) CLLC 16, 013.
(3) 
The reply here is, I suppose, that the Board is open to be convinced that a majority of the employees would have adhered to the union even without the picketing. I wonder, though, if in fact indulgence in organizational picketing would not effectively preclude the union from ever representing the employees.

Recognition picketing is met by section 64 (4) which provides,

(4) Where an agreement is negotiated between an employer and a trade union as a result of the employer's recognition of the trade union as bargaining agent, if the recognition directly resulted from picketing of the place of business of the employer at which the employees affected are employed, or elsewhere, the agreement shall be deemed not to be a collective agreement for the purposes of this part.

The effect of this provision is, obviously, to render the agreement of little use to the union. There would be no bar to a certification application by another union and there would be no remedy by arbitration or other legal means if the employer failed to abide by the agreement. It is, nevertheless, worthy of conjecture whether a strong union might not be quite happy to find such a modus vivendi with the employer outside the framework of the labour relations law.

Neither of these provisions is a prohibition of recognition or organizational picketing, and it appears that recognition picketing is not prohibited outright by the Alberta Act. Under section 95 picketing is illegal "where a strike is illegal". This could mean that in a situation where a strike is, or would be, illegal, it is illegal to picket. Picketing is illegal, that is, even though there is not actually any illegal strike. This reading is consistent with what I take to have been the intent of the section: to outlaw all untimely economic pressure. Moreover, the words of section 95 appear to be a shorthand version of the British Columbia statute of $1959^{12}$ which prohibits all picketing except in support of a legal strike. It has been suggested, however, that section 95 only outlaws picketing where there actually is an illegal strike, and does not follow the B.C. precedent. ${ }^{13}$

To come back to the point: the question with regard to organizational and recognition picketing is whether it would be illegal for the employees to strike at this stage. With regard to recognition picketing Section 95 provides, it will be recalled, that a strike is illegal where it is in contravention of section 94 and section 94 provides that, and here's the catch, "where notice of a [bargaining] meeting . . . has been served by either party" the conciliation procedure must be exhausted before there can be a strike. If the employer gives notice in order to bring section 94 into effect in so doing he has, of course, recognized the union, which is what it is after. If he does not give notice to bargain there

12 Now R.S.B.C. 1960 , c. 384 , s. 3, which provides:

3 (1) Where there is a strike that is not illegal under the Labour Relations Act or a lock-out, a trade union, members of which are on strike or locked out, and or a lock-out, a trade une trade union may, at the employer's place of business, operations or employment, and without acts that are otherwise unlawful, persuade or operations or employment, and without

(a) enter the employer's place of business, operations or employment; or

(b) deal in or handle the products of the employer; or

(c) do business with the employer.

(2) Except as provided in subsection (1), no trade-union or other person shall persuade or endeavour to persuade anyone not to

(a) enter an employer's place of business, operations or employment; or

(b) deal in or handle the products of any person; or

(c) do business with any person.

13 This comment was made from the floor by Dr. K. A. Pugh, Deputy Minister of Tabour and Chairman of the Board of Industrial Relations of Alberta, when this paper was presented to a Seminar of the Alberta Bar in April, 1969 at Banff. 
seems to be no statutory bar to a strike, ${ }^{14}$ except the requirement of a strike vote. There may lie the practical answer, because there is no procedure spelled out for getting a strike vote set up by the Board. It might be that a union simply could not get the necessary vote in a recognition strike. In the case of organizational picketing the strike vote requirement amounts to an effective bar because if the union needs to picket to gain employee support by hypothesis it will lose the strike vote. In a case of recognition picketing, on the other hand, the union may well have the support of a majority of the employees.

Even if the Board did take a vote, the result of which supported the strike, the union would be unwise to picket in support of a recognition strike because the Board would then have good grounds for holding that, by virtue of section 64(4), any ensuing agreement was invalid as having resulted from picketing. The fact remains that the picketing would not be enjoinable on statutory grounds. It seems likely though, as I pointed out at the start, that the courts would enjoin the picketing on the ground that it constituted an inducement of breach of contract. But if the union was able, by the strike alone without picketing, to move the employer to sign an agreement they would appear to be home free. ${ }^{15}$ I hasten to emphasize once again that the legality of the recognition strike is dependent on getting the Board to take a vote at this pre-conciliation stage. ${ }^{16}$ I leave open the question of whether the Board would arrange to hold such a vote and whether, if they refused, mandamus would be available.

Where the union has been certified it will give notice to bargain, and if the union fails to do so the employer may give the notice, so that any strike would then be illegal until the conciliation procedures, which include an employee vote on the conciliation award and the strike vote, have been exhausted. By section 94 (5) the employer must also be given two days' notice of the strike. Thus, it is illegal for any employee t? strike during conciliation and, by virtue of section 95 , it would be illegal to picket during any such strike. ${ }^{17}$

14 One may muse over the question of whether a recognition strike would be held to fall within the Alberta definition of a "strike" at all. The definition in section 55 (1) (1) of the Labour Act specifies the "purpose" of compelling the employer to accept "terms and conditions of employment". Surely union recognition is a "condition of employment". and anyway, the definition commences with the words "strike' includes". If, nevertheless, the Board refused on these grounds to hold a strike vote then, unless the courts were to be inconsistent with the Board, the cessation of work and any picketing would be left to the tender mercles of the common law. Judicious use of such tort concepts as inducing breach of contract and conspiracy would virtually ensure that any picketing under such clrcumstances would be enjoined.

15 The Taft-Hartley amendments to the U.S. National Labour Relations Act, s. 8(b) (7), severely limit recognition picketing but do not prohibit a recognition strike. Indeed. where it subsequently proves to have been the fact that the union had majority support at the time it claimed recognition unless the employer had grounds for doubt, he will be held to have committed an unfair labour practice in refusing doubt, he will be held to have committed an unfair labour practice in refusing labour relations legislation in Canada it may well be that the intent of the Alberta legislature was to allow recognition strikes. The strike vote requirement, of course, ill accords with this conclusion, unless it is assumed that the Board of Industrial Relations will view any recognition strike as perfectly legitimate.

10 Any impropriety in the strike vote will render the ensuing strike illegal. See Association of Calgary Contractors v. I.B.E.W. (1963) 40 D.L.R. (2d) 907 (Alta. S.C.). See also Jacobsen Brothers Ltd. v. Anderson 196235 D.L.R. (2d) 746 (N.S.S.C. en banc)

17 In Canadian jurisdictions other than Alberta, British Columbia, and Newfoundland picketing during conciliation is not explicitly rendered lilegal although a strike is. The decisions of the Ontario High Court in the Nipissing case, however, make it quite clear that such picketing will not be allowed, even where there is no strike. In Nipissing the injunction was granted and continued on the ground that the union leadership had induced the picketing employees to breach their contractual obligation to further the interests of their employers in good faith. See Nipissing Hotel Hotel and Restaurant Employees and Bartenders International Union (1962) 36 D.L.R. (2d) 81 (Ont. H.C.) and (1963) 38 D.L.R. (2d) 675 (Ont. H.C.). 
It is worth mentioning, perhaps, that there is no specific provision in the Alberta Act attaching a penalty to illegal picketing. The penalties provided in sections 96 and 97 are for an illegal strike. Presumably therefore, the general penalty set out in section 126, a fine of not more than $\$ 250.00$ and, in default of payment, imprisonment for a term not exceeding 90 days, applies to those who picket illegally. This general penalty is a harsh one to be applied to picketing which, although it is untimely, may nevertheless be otherwise objectionable. The fine provided for participation in an illegal strike is, after all, only a maximum of $\$ 25.00$ a day for individual employees. ${ }^{18}$ By section 126 the consent in writing of the Minister charged with the administration of the Act is required before any of these prosecutions may be launched. ${ }^{10}$

Moving now to the case of picketing during the life of a collective agreement, it is reiterating the obvious to point out that such picketing is illegal. There is, however, a new consideration under these circumstances in that the employer may seek his remedy in arbitration. Under section $73 a$, enacted in $1968,{ }^{20}$ it would appear that even if there is no provision in the collective agreement for employer grievances, the employer could invoke the arbitration procedure. Section $73 a$ (2) (a) provides,

If any difference concerning the interpretation, application, operation or any alleged violation of this agreement ... arises between the parties or persons bound by the collective agreement, such parties or persons shall meet and endeavour to resolve the differences (emphasis added)

The subsequent paragraphs provide for arbitration in the event that the parties are unable to resolve the differences referred to. Thus, where the agreement contains a no-strike clause the employer will have an arbitrable grievance, and, according to the Supreme Court of Canada's decision in the Polymer case, ${ }^{21}$ the arbitrator is entitled to award damages against the union even where the power to do is not spelled out in the agreement."2 If the agreement does not contain a no-strike clause then the strike is a breach only of the Act and arbitration would not be available. ${ }^{23}$

In Ontario employers not uncommonly seek redress through arbitration for injury caused by illegal strikes and picketing because under the Ontario Rights of Labour Act a union may not, by virtue of provincial labour relations legislation, be made a party to any action in any court. $^{24}$ But in Alberta presumably the Supreme Court's decision in the Therien case, ${ }^{25}$ in which a British Columbia union has held to be a suable entity, applies to make the union suable as well as subject to penalty under the Labour Act. In this province, therefore, an employer

18 Alberta Labour Act, R.S.A. C. 167, (as amended) s. 96(3).

10 That is, for picketing for recognition where there has not been an affirmative strike vote, for picketing during conciliation or for picketing during the term of a collective agreement.

20 S.A. 1968 , c. 51, s. 16.

20 S.A. 1968, c. 51, S. 16. Oil, Chemical and Atomic Workers, Local 16-14 (1961) 26 Re Polymer Corp. and Oil, Chemical and Atomic Workers, Local 16-14 (1961) 26 Nom Imbleau v. Laskin (1962) 33 D.L.R. (2d) 124 (S.C.C.).

22 The Alberta Labour Act differs from the Ontario Labour Relations Act in that sec. $73 a(8)$ provides that "no arbitration board shall by its award, alter, amend or change the terms of a collective agreement." This does not, however, appear to stand in the way of an arbitral award of damages. In the Polymer case the agreement did not way of an arbitral award of was) held that this power was implicit in his power to grant "final settlement". The Supreme Court of Canada upheld the award on this point.

23 Supreme Court of Canada upheld the award on this point. include a no-strike clause although such strikes are also directly prohibited by The Ontario Labour Relations Act. R.S.O. 1960 , c. 202, ss. 33 and 54 (1).

24 R.S.O. 1960 , c. 354, s. 2.

26 International Brotherhood of Teamsters v. Therien [1960] S.C.R. 265. 
would probably choose to seek his damages in the courts where, by common consensus, he fares better than at arbitration.

That brings me to the end of my consideration of picketing in support of unlawful strikes. The short of it is that the courts will not put up with picketing except where there is no collective agreement in force and the conciliation procedures set up in the Act have been exhausted. In Alberta section 95 spells that out, except for recognition or organizational picketing, but section $64(3)$ and (4) meet those activities head on by denying unions most of the benefits that they stand to gain by such picketing. A strong union may feel, of course, that it does not need the support of the labour legislation. The Alberta Act is unique in Canada in that it does not outlaw recognition strikes, although, like any other strike in Alberta, a recognition strike must be preceeded by a strike vote.

The law relating to picketing in support of a lawful strike is more difficult. In this connection I will consider first primary picketing and then secondary picketing; and it must be borne in mind that any of the grounds of illegality outlined below may be and frequently are invoked in cases of picketing in support of unlawful strikes as well.

Section 366 of the Criminal Code prohibits, among other things, "wrongfully and without lawful authority" besetting or watching "the dwelling house or place where [a] person resides, works, carries on business or happens to be". In my view the Supreme Court of Canada decision in Williams v. Aristocratic Restaurants Ltd. in $1951^{20}$ established that section 366 does nothing more than add penal sanctions to picketing that is unlawful on some other ground, whether criminal or tortious. Thus, for example, picketing in contravention of section 95 of the Alberta Labour Act is also criminal, as is picketing on any of the grounds that I shall be considering shortly. There have, however, been virtually no reported cases of prosecution under section 366 since 1945.27 The section finds its way into the law reports usually as a false buttress to a decision that picketing is unlawful on some other grounds. It is a false buttress because in the normal injunction case it is quite superfluous for the court to say, in effect, "this picketing is tortious or prohibited by the provincial labour legislation, therefore it is wrongful besetting contrary to section 366 ; section 366 gives rise to a civil right of action [an interesting constitutional sidelight there] and the picketing will be enjoined." In a labour context I suggest that section 366 is virtually functionless. ${ }^{28}$ The Task Force refused to recommend the repeal of the section on the ground that, ${ }^{20}$

We are concerned here with the capacity of picketing as an act of free speech and legitimate persuasion to erupt into extravagant or outrageous behaviour. We are particularly concerned with constraining industrial conflict from taking the form of harassment of domiciles or places of residence or other forms of interference with the right to privacy.

I suggest, on the contrary, that section 366 ought to be repealed. The problem of freedom of speech in picketing and demonstrations generally deserves the kind of explicit attention which the repeal of section 366 might gain for it, and the section as it stands has little relation to the issue in its modern forms.

\footnotetext{
26 [1951] S.C.R. 762.

27 The last was $R$. v. Carruthers (1946) 86 C.C.C. 247 (Ont. Cty. Ct.).

28 In $R$. v. Elford (1947) 87 C.C.C. 372 (Ont. Mag. Ct.) the accused was convicted of watching and besetting the home of his estranged wife.

29 Supra, n. 2, at 183.
} 
The question, then, still is upon what grounds may picketing in support of a legal strike be enjoined, or when should it give rise to an action in damages. The grounds of action may be broken into two groups: the industrial torts and the torts of general application. The Task Force recommended, and here I agree with them completely, that the industrial torts should be legislated out of existence.30 $\mathrm{By}$ "the industrial torts" I mean the torts of conspiracy, intimidation and inducing breach of contract. I do not propose to spend much time on the conceptual niceties of these torts.

The tort of conspiracy may consist either in an agreement to cause economic injury without legal justification by means that are lawful in themselves, or it may consist in an agreement to cause economic injury by means that are in themselves unlawful. The first branch of the tort, "conspiracy to injury", was developed in the early part of this century as a weapon of judicial anti-unionism. ${ }^{31}$ I suggest that since 1942 , when the House of Lords held in the famous Crofter's case ${ }^{32}$ that normal trade union activities constituted "justification" within the terms of the tort, conspircacy to injure has been of no legal significance in this country. It appears in the language of the courts, but only when there is some other ground upon which the picketing can be enjoined.

The second branch of the tort, conspiracy to do an act in itself unlawful, should be superfluous. For there to be a cause of action in conspiracy, in contrast with criminal conspiracy, the unlawful agreement must have been put into effect. Thus it might seem that since the acts agreed upon and committed must themselves be unlawful there is no need to allege conspiracy. In fact, however, this second type of conspiracy has served three purposes in the reported cases: first, it has enabled the courts, in the leading Supreme Court case of Gagnon v. Foundation Maritime ${ }^{33}$ for instance, to hold that where there is an illegal strike picketing in support, although not expressly prohibited by the provincial statute, is unlawful as part of a conspiracy to achieve the unlawful object of the strike. In Alberta, of course, such picketing is expressly prohibited by section 95 of the Labour Act. Second, where an action is framed in terms of conspiracy the court need not concern itself with the question of whether the labour relations act gives the employer a private right of action against the strikers. I leave you with the academic question of whether the Alberta Act, with its statutory penalties and the requirements of ministerial consent, ${ }^{34}$ manifests an intent that there be a private right of action. Third, in a conspiracy action liability attaches to everyone who is part of the agreement to picket illegally, not just to the pickets themselves. It is an easy way to get at the union officials. In short, whatever grounds there are for enjoining picketing it will always be to the employer's advantage to frame the claim in terms of "a conspiracy to ...."

The so-called tort of intimidation ${ }^{35}$ is really part of a broader head

80 Id., at 180. ship" (1960) 38 Can. Bar Rev. 346. Christie, The Liability of Strikers in the Law of Tort (1967) 68-83.

32 Crofter Hand Woven Harris Tweed Co. v. Veitch [1942] A.C. 435.

33 [1961] S.C.R. 435 .

34 Alberta Labour Act, R.S.A. 1955 c. 167, (as amended) s. 126.

35 In the recent House of Lords decision in Rookes v. Barnard [1964] A.C. 1129, which established that one who is intentionally caused economic harm by the threat of a breach of contract delivered against a third party has a cause of action, the basis of llability was called "intimidation". 
of tort liability. It is actionable to intentionally cause economic injury to an employer or any other person, "to $A$ " as we like to say, by means of an unlawful act directed against $B$. Thus in the Therien case ${ }^{30} \mathrm{Mr}$. Therien recovered for the loss which he incurred when he was denied further contracts as a result of union pressure brought to bear by the illegal picketing of City Construction Company, for whom he had been working as an independent contractor. Note that in real terms what is involved here is secondary pressure. Note too, the differences between the Therien case of action and the second type of conspiracy. Both require that there be an act in itself unlawful by which the plaintiff is intentionally injured but in the Therien cause of action, for one thing, the illegal pressure is directed not against the plaintiff but against a third party and, for another, there is no element of collective action required.

More devastating from a labour point of view than either of the other two industrial torts is the tort of inducing breach of contract. In a non-labour law context Chief Justice Gale of Ontario defined that tort in these terms: ${ }^{\text {st }}$

[I]f a person without justification knowingly and intentionally procures the breach by a party to a contract which is valid and enforceable and thereby causes damage to another party to the contract, the person who has induced the breach commits an actionable wrong.

The Alberta case of Bennett and White, ${ }^{38}$ which was mentioned earlier, is a good example of the application of this doctrine in the context of picketing. When members of the Carpenters' Union refused, in accordance with the rules of their union, to cross the picket line, they were held to be in breach of their contracts of employment and the breach was held to have been induced by the pickets. Mr. Justice Johnson held that it was sufficient that the pickets knew that the carpenters were under contract of employment, knowledge of the exact terms was irrelevant, and further, the intention to induce breaches could be presumed since it was the natural consequence of the picketing. The reasoning in the case might be criticised, on the grounds for instance, that since the carpenters could leave work at any time by merely giving notice, there was no reason for the court to conclude that they were being persuaded to quit without notice. But the real point is that if the tort of inducing breach of contract is applied freely in picketing cases it destroys the right to picket even where the strike is perfectly legal under the Act. After all, the legitimate purpose of a picket line is to cut off the employer's economic lifelines by means of rational persuasion. Does it make any sense to draw the line where the relationship interfered with happens to be one that satisfies the formalities of the law of contract as opposed to one where there is an established course of dealing or other grounds for a strong expectation of economic advantage? In this country the courts have on several occasions in labour cases gone beyond the limits of the tort of inducing breach of contract to enjoin picketing or award damages on the ground that there has been an "interference with contractual relations". On examination "interference with contractual relations" proves to be interference with one of these relationships that has not ripened into contract. In a few cases the facts are that the union has pressured an 
employer to breach some of his own trade contracts and the employer himself has been allowed to recover from the union, even though the means of putting pressure on him were not in themselves illegal.

Even in its narrow form, and certainly in this broad form, the tort of inducing breach of contract will serve as a ground upon which to establish the illegality of most picketing, including picketing in support of a timely strike. Why then is not all such picketing enjoined? The answer must surely be that the judiciary in general has a sense that modern labour relations legislation contemplates limited peaceful picketing where a strike is legal. Nearly all inducing cases in recent years involve picketing which was offensive to the judge on some real life industrial relations ground, usually because it was secondary ${ }^{39}$ or untimely under the applicable labour relations act. In Bennett and White, for example, the picketing was organizational.

The fact remains that peaceful, timely picketing often does interfere with contractual relations and frequently induces the breach of actual contracts. I would, therefore, much prefer a codification of the law of picketing that explicitly abolished the tort of inducing breach of contract in labour law, and tortious conspiracy and intimidation along with it. These tangled conceptualizations should not determine the limits of the right to picket. The limits should be set on the basis of a rational assessment of when, where and how picketing should be allowed in the context of the Canadian system of collective bargaining.

How picketing may be carried on, behaviour on the picket line if you like, is a matter of the generally applicable law of torts and crimes. The Task Force has recommended that the law continue to be applied, unchanged, by the ordinary courts, and here I take issue with them. The general torts with which we are concerned are acts of violence, assault and battery, trespass to property, defamation and nuisance. Violence must not, of course, be allowed. Generally speaking private individuals who are injured have private rights of action and normal police protection is, or should be, available. Frequently, in fact, the police are unwilling or unable to act and the person injured is unable to identify any one assailant. Thus, if support for the violence can be brought home to the picket line as a whole, the picketing should and will be enjoined.

Trespass is somewhat more difficult. Probably the law is that any picketing on the employer's property will be enjoined, but this may not be desirable where the trespass is necessary if there is to be a picket line at all. Picketing a store in a shopping centre, ${ }^{40}$ or picketing a forest operation where the only access is by private road will serve as examples. Surely in such cases the question must at least be asked whether the law of labour relations contemplates the use of pickets in support of legal strikes.

Similarly with the tort of defamation, when a court is faced with determining the impact of a picketing sign in terms of its message, the size of the letters and the facts of the dispute, ${ }^{41}$ the real question is not whether the traditional criteria of the tort have been met, but

30 E.g. North Fork Timber Co. Ltd. v. MacKenzie (1964) 45 D.L.R. (2d) 79 (Alta. S.C.).

10 See Zeller's (Western Ltd.) v. Retail Clerks' Union, Local 1518 (1962) 36 D.L.R. (2d) 581 (B.C.C.A.) and Grosvenor Park Shopping Centre v. Cave (1964) 46 D.L.R. (2d) 750 (Sask. C.A.).

11 See F. W. Woolworth Co. Ltd. v. Retail Food and Drug Clerks Union, Local 1518 (1961) 30 D.L.R. (2d) 377 (B.C.S.C.). 
rather, whether the limits of permissible economic pressure have been exceeded. Even more so is this the case with the tort of nuisance. In Fleming on Torts the author comments: ${ }^{42}$

The gist of private nuisance is interference with the occupier's beneficial use of his land .... in order to merit legal intervention, the annoyance and discomfort must be substantial and unreasonable. . . Much depends on the social value which the law attaches to the object the defendant is pursuing.

In the Aristocratic Restaurants case the Supreme Court established that peaceful picketing does not constitute actionable nuisance merely because it interferes to some extent with the employer's business operation. ${ }^{43}$ Thus, it seems to me that the concept of legal nuisance is relevant in cases of mass picketing and the blocking of ingress and egress to and from the employer's premises. It must be the tort of nuisance that constitutes the legal underpinning for the familiar case where the judge specifies in the injunction how many pickets may stand at each gate of the employer's plant. The judge decides in other words, how many pickets will cause the employer unreasonable discomfort or annoyance, "unreasonable" that is, in light of the social value which in the judge's opinion the law attaches to picketing. The whole purpose of the picketing is, of course, to cause the employer discomfort.

My objection, simply stated, is that this decision should not be left to the judges in the ordinary courts. The Task Force recommended that the control of picketing in terms of timeliness and in terms of who may be subjected to pressure should be given over to the Labour Relations Boards. I suggest that it is even more important that matters of number and placement of pickets should be given over to the Board. The Board would be specialized enough to develop a consistent jurisprudence and flexible enough to change its orders on short notice on the advice, perhaps, of field officers who observe the behaviour of the pickets. As a rough rule I would suggest that the union should be allowed the maximum number of pickets that would not physically block ingress or egress or constitute an overt threat of attack or reprisal on those who wished to cross the line. A failure to behave peacefully could result in a reduction of the allowed number of pickets. As I understand the recommendations of the Rand Commission, they are substantially along these lines. ${ }^{44}$ Like $\mathrm{Mr}$. Justice Rand, ${ }^{45}$ I recognize that in the provincial sphere section 96 of the B.N.A. Act, as it now stands, may well preclude the establishment of an administrative tribunal with such powers.

To return to "the law as it is"; I can sum up the law of primary picketing by putting the hypothetical cause of four pickets standing peacefully at the main gate to the employer's plant. The first question is "does the Labour Act allow a strike at this stage in the labourmanagement relationship?" If it does the next question is, "Are the pickets committing or threatening any unlawful act against those who wish to deal with the employer?" Then, are they trespassing on the employer's property, are their signs untrue or misleading, or are they blocking ingress or egress from the plant? If they are doing none of these things there remains only the question of whether merely by their presence the pickets are inducing breaches of contract or constitute an

42 Fleming on Torts (3rd ed. 1965) 321-3.

43 [1951] S.C.R. 762, per Kerwin J. (Estey J. conc.) at 780; per Kellock J. at $158 \mathrm{ff}$; per Rand $J$. at $783-5$

44 Supra, n. 1, at 76.

45 Id., at 96. 
undue intereference with the employer's enjoyment of his property and thus a legal nuisance. The answer will depend on how effective the pickets are, and on the judge.

Picketing is termed secondary where the union's real dispute is not with the enterprise being picketed but with another employer with whom the primary employer has some relationship. The union's aim is to put pressure on the primary employer by forcing the third party to cease buying from or selling to the employer or, perhaps, to stop doing work that has been contracted out as a result of the strike.

Section 95 (2) of the Alberta Labour Act, it may be recalled, provides that "where a strike is illegal" no person shall picket. That provision may well be interpreted as outlawing secondary picketing. In other words, a strike at the secondary enterprise would be illegal so the picketing there is illegal. On the other hand, it could be argued that secondary picketing in support of a legal strike is not prohibited by the Act. Decisions under the British Columbia Trade-Union Act support the first interpretation ${ }^{46}$ and even if the Labour Act does not prohibit secondary picketing, it would be almost certain to be enjoined on common law grounds. The torts of intimidation, that is the "Therien" cause of action, and inducing breach of contract wil be readily available. In North Forks Timber Company Ltd. v. Mackenzie. ${ }^{4 i}$ for instance, Mr. Justice Kirby of the Alberta Supreme Court enjoined picketing which he plainly considered to be secondary on the ground that it induced breaches of contract.

It is now established in Ontario that secondary picketing is per se unlawful at common law. In Hersees of Woodstock v. Goldstein ${ }^{18}$ in 1963 Mr. Justice Aylesworth, speaking for the Ontario Court of Appeal, said,"9

But even assuming that the picketing carried on by the respondents was lawful in the sense that it was merely picketing, I think it should be restrained. ... The right, if there be such a right, of the respondents to engage in secondary picketing of appellant's premises must give way to appellant's right to trade; the former, assuming it to be a legal right, is exercised for the benefit of a particular class only, while the latter is a right far more fundamental and of far greater importance, in my view, as one which in its exercise affects and is for the benefit of the community at large ...

The difficulty with this truly classic piece of judicial labour legislation, as with the Alberta and British Columbia statutory provisions, is that it is quite lacking in any sophisticated discrimination among the various types of secondary picketing. The American courts, with their twenty years of experience under the secondary picketing provision in the Taft-Hartley Act, have come to distinguish three situations in which picketing is held to be not truly secondary, in the sense prohibited by the Act: Under the "ally doctrine" the union may picket the premises of a third party employer who allies himself with the struck plant by taking over part of its production, whether or not there is a corporate relationship." Second, under the "common-situs" rules where the struck employer is carrying on his operations on the third party's premises the premises may be picketed to the extent necessary

46 Coles Baker Ltd. v. Retail, Bakery and Confectionery Workers Union (1962) 36 D.L.R. (2d) 772 (B.C.S.C.)

47 (1964) 45 D.L.R. (2d) 79 (Alta. S.C.).

48 (1963) 38 D.L.R. (2d) 449 (Ont. C.A.)

40 Id., at 454 .

so Douds v. Metropolitan Federation of Architects 75 F. Supp. 672 (1948-S.D.N.Y.); N.L.R.B. v. Business Machines and Office Appliance Mechanics 228 F. $2 d 553$ (19552d Cir.). 
to publicize the dispute to anyone dealing with the struck employer. ${ }^{51}$ This has led to the use of the reserved gate for construction employees working on industrial premises. Third, the U.S. Supreme Court has allowed "product picketing". ${ }^{2}$ That is, in a dispute with a producer the union may picket a retail outlet as long as the pickets' appeal is addressed solely to the consumer and not to the retailer's employees.

In British Columbia a very rudimentary "ally doctrine" has developed, and some heed has been paid to the situs problem. ${ }^{53}$ Consumer picketing has not been viewed with sympathy by Canadian courts. Indeed, the Hersees case which outlawed secondary picketing in Ontrario was a clear case of "product picketing". However, both the Rand Commission Report ${ }^{\text {i4 }}$ and the Task Force Report ${ }^{55}$ recommend that the "ally doctrine" be adopted in Canadian law and the Task Force is most emphatic in recommending that secondary consumer picketing be made legal in all cases. $^{56}$ After all, all that a retailer need do to rid himself of the pickets is to cease selling the struck goods, and effective primary picketing which would be quite lawful could just as surely cut off the flow of goods between the secondary and the primary employer. Thus the retailer is not really a helpless man-in-the-middle. In outlawing consumer picketing what the Ontario Court of Appeal was really saying was simply that the freedom to carry on such picketing gave the union too much power in its dispute with the primary employer. That is not, I suggest, a proper function for the Court. The same objection cannot be taken to the British Columbia and Alberta law. I only wonder whether in passing section 95 of the Alberta legislature saw itself as attempting to find the most socially desirable balance of bargaining power between labour and management; or was it outlawing activity that was considered to be in some sense "immoral".

If I may now summarize the grounds upon which picketing may be held to be illegal, stressing the remedies that are available in each case. First, picketing will be illegal where it is carried on in conjunction with an untimely strike, or perhaps where a strike would be illegal if one were called. Thus organizational picketing, picketing during the conciliation procedure and picketing during the life of the collective agreement are clearly illegal. Recognition picketing is not necessarily so. Any such untimely picketing may give rise to an action in damages, framed in terms of the tort of conspiracy or, perhaps directly, on the assumption that the legislature intended to create a private right 0 action when it passed section 95 of the Labour Act. Where the picketing is illegal because it occurs during the term of the agreement resort may also be had to arbitration. The employer may recover damages for any injury he has suffered as a result of either the picketing or the strike itself. Of greater practical importance, the employer will be able to have

51 Local 761, I.U.E. v. N.L.R.B. (The General Electric Case) 336 U.S. 667, 81 S.Ct. 1285,

52 N.L.R.B. v. Fruit and Vegetable Packers and Warehousemen (1964) 337 U.S. 58, 84 S.Ct. 1063 .

53 The British Columbia courts have refused to enjoin the plcketing of a chain store carried on in support of a legal strike at another store in the chain. See Taylor, Pearson and Carson (B.C.) Ltd. y. Retails, Wholesale and Department Store Union (1962) 31 D.L.R. (2d) 367 (B.C.S.C.), followed in Crestbrook Industries v. I.W.A. (1967) 68 CLLC 14, 093 (B.C.S.C.). For a recognition of the situs problem see Biue Star Line (1959) 29 W.W.R. 337 (B.C.S.C.). Tenen Investments v. Mueller (1966) 66 CLLC 14, 151 (Ont. H.C.) and Nichol v. MacLaren (1965) 51 D.L.R. (2d) 667 (Alta. S.C.).

st Supra, n. 1, at 77.

65 Supra, n. 2, at 18i, 182

so Id. 
any such picketing enjoined; and, since the recent Supreme Court of Canada decision in the Winnipeg Builders ${ }^{67}$ case, it now apears that the courts may enjoin the illegal strike itself; certainly they may do so where the strike occurs in breach of a collective agreement.

Sections 96 and 97 of the Act provide penalties for involvement in an illegal strike by trade union officials and by employees, and against the union itself. Section 97, in a passage that is unique in Canada, provides for recovery of fines through a judicially enforced 'check-off". The penalty for illegal picketing is apparently the general penalty under section 126. Any prosecution under the Act requires the consent of the responsible Minister.

In addition to damages, the injunction and the penalties set out in the Act, organizational and recognition picketing in Alberta will also subject the union to special disabilities in that the union will not be certified where it has organized through picketing, and its collective agreements will not be valid where it was recognized as a result of picketing.

The second ground upon which picketing will be illegal is that it constitutes the tort of conspiracy, intimidation or inducing breach of contract. Where any of these are established the picketing may be enjoined and damages awarded. Tortious conspiracy and intimidation both require as a necessary component that there be some act in itself unlawful, apart from the conspiracy or intimidation, but inducing breach of contract is important entirely in its own right as a ground upon which picketing has frequently been enjoined.

Third, any criminal activity; assault, unlawful assembly, criminal breach of contract or mischief, for example, may be prosecuted as such. Any tort committed on the picket line is actionable. If a conspiracy to commit any of these unlawful acts is alleged damages may be obtained against all those involved, if the agreement between them is established. The picketing may be enjoined if the picket line as a whole is implicated. The torts of trespass, defamation and nuisance, deserve special notice since they involve issues at the core of the right to picket. Where the elements of these torts are established, hopefully in the light of a sensitive understanding of the policy implications of labour relations law, damages may be awarded and an injunction will issue. In most cases the court will enjoin only those aspects of the picketing which constitute a trespass, defamation or nuisance. Thus the courts are cast in the role of administering the picketing. In fact, what frequently happens is that counsel agree on the wording of an injunction order that allows limited picketing and it is then approved by the judge.

The fourth ground upon which picketing will be held to be illegal is that it is secondary and therefore, as I read the Alberta Act, prohibited by section 95 . Thus secondary pickets are subject to the general penalty as well as damages and an injunction.

Finally, in any case where the courts would hold the picketing to be unlawful, a prosecution for wrongful and unlawful watching and besetting contrary to section 366 of the Criminal Code could be launched.

Of all these remedies much the most important to both labour and management is the injunction. Time is all-important on the picket line.

s7 International Brotherhood of Electrical Workers v. Winnipeg Builders Exchange [1967] S.C.R. 628. 
If the union is to make an impact it usually must do so early in the strike because its institutional structure is such that in most cases it does not have the staying power that the employer has. Therefore, if an injunction issues immediately the course of the dispute will be turned, even if the injunction is for a brief period and is not continued. If the picketing is illegal there is, of course, no reason why it should be allowed, even temporarily. To some extent union objections to the use of the injunction boils down to a claim that they should be allowed to indulge in activities that the law now prohibits. I must agree with them that the substantive law needs changing, and I do think that the law would be better administered by a special tribunal, but the fact is that this is really not an objection to the injunction as such.

More peculiar to the injunctive remedy are the union charges that the ex parte issue of injunctions has led to perfectly legal picketing being enjoined, either because the affidavits misrepresented the facts or because the court, without benefit of opposing counsel, misapplied the law. The unions also object to the granting of injunctions on the basis of affidavits rather than viva voce evidence and cross-examination, to the encompassing within the terms of the injunction of persons not party to the action, to the absence of a right of appeal from interlocutory proceedings, and to the criminal sanction of contempt of court with a limited right of appeal.

Section 94a of the Alberta Labour Act, enacted in 1968, provides;

94a (1) Notwithstanding anything in this Act, the Judicature Act or any other Act, where a lawful strike or lockout exists in a labour dispute, no injunction before trial shall be granted ex parte to restrain any party to the dispute or any other person from doing any act in connection with a strike or lockout.

By subsection 2 affidavits are confined to statements of fact which the deponent of his own knowledge is able to prove, and a copy thereof must accompany the notice of motion, which must be served not less than three hours before the time fixed for the hearing.

In closing, I will only point out that section 94a does not respond to most of the union charges against the injunction. The ex parte injunction is, in many cases, prohibited but three hours hardly gives counsel time to prepare countering affidavits. I realize, of course, that Alberta courts may in fact allow more time and may permit evidence and crossexamination, but section 94a does not so provide. Further, the section only does away with ex parte injunctions where there is a "lawful" strike. Thus, wherever the employer alleges an unlawful strike an injunction may be granted without notice. This may be justified, I supose, on the ground that the employer's counsel could hardly, in good faith, introduce affidavits establishing the untimeliness of a strike which is in fact legal. Certainly, if the appropriate undertaking is given to compensate the union should the injunction prove to have been improperly obtained there would be no difficulty in establishing subsequently that the strike had been timely. The Labour Act should, perhaps, make specific provision for the filing of security in an amount truly commensurate with what the union stands to lose by an improper injunction. The law must ensure that an employer not be made to suffer improper picketing, but in the past the courts have never neglected his interests. It is the protection of the union that must be most clearly spelled out in legislation. 